\title{
Calculation of Radiogenic Heat Productions from Marble and Glazed Tiles Used as Covering Building Materials in Turkey
}

\author{
Aybaba HANÇERLİĞULLARI*, Şeref TURHAN, Aslı KURNAZ \\ Kastomunu University, Faculty of Science and Letters, Department of Physics, 37150, \\ Kastamonu, Turkey \\ (ORCID: 0000-0001-7008-480X)(ORCID: 0000-0001-5303-3680) (ORCID: 0000-0002-7910-3461)
}

\begin{abstract}
In this study, radiogenic heat productions of marble and glazed tiles samples are calculated based on the elemental concentrations of uranium (in terms of $\mathrm{mg} / \mathrm{kg}$ ), thorium (in terms of $\mathrm{mg} / \mathrm{kg}$ ) and potassium (in terms of $\%$ ) in the samples collected from various provinces in Turkey. The radiogenic heat productions from the marble tile samples varied from 0.05 to $2.17 \mu \mathrm{W} / \mathrm{m} 3$ with an average of $0.26 \mu \mathrm{W} / \mathrm{m} 3$. The average of the radiogenic heat production of the marble tile samples is approximately four times lower than the average continental crust of $0.9 \mu \mathrm{W} / \mathrm{m} 3$.
\end{abstract}

Keywords: Marble, Radiogenic heat production, Building materials.

\section{Türkiye'de kaplama yapı malzemesi olarak kullanılan mermer ve sırlı karolardan radyojenik ısı üretiminin hesaplanması}

\section{Öz}

Bu çalışmada, Türkiye'nin çeşitli illerinden toplanan mermer ve sırlı karo örneklerinin radyojenik 1sı üretimi, uranyumun (mg/kg cinsinden), toryumun ( $\mathrm{mg} / \mathrm{kg}$ cinsinden) ve potasyumun (\% cinsinden) temel konsantrasyonlarına göre hesaplanmıştır. Mermer karo örneklerinden elde edilen radyojenik 1sı üretimi, ortalama $0.26 \mu \mathrm{W} / \mathrm{m} 3$ olam üzere 0.05 ile $2.17 \mu \mathrm{W} / \mathrm{m} 3$ arasında değişmektedir. Mermer karo örneklerinin radyojenik 1s1 üretiminin ortalaması, $0.9 \mu \mathrm{W} / \mathrm{m} 3$ ortalama kıtasal kabuk değerindenyaklaşık dört kat daha düşüktür.

Anahtar kelimeler: Mermer, Radyojenik 1sı üretimi, Yapı malzemeleri.

\section{Introduction}

The radioactive elements that cause this are divided into two groups as short and long half-life isotopes. Long half-life radionuclides such as the member of natural radioactive series of uranium ${ }^{\dagger}\left({ }^{238} \mathrm{U}\right)$, thorium $\left({ }^{232} \mathrm{Th}\right)$, actinium $\left({ }^{235} \mathrm{U}\right)$, and radioactive potassium $\left({ }^{40} \mathrm{~K}\right)$. The two main radionuclides, ${ }^{238} \mathrm{U}$ (half-life of $4.5 \times 10^{9} \mathrm{y}$ ) and ${ }^{235} \mathrm{U}$ (half-life of $0.7 \times 10^{9} \mathrm{y}$ ), decay into lead, ${ }^{206} \mathrm{~Pb}$ and ${ }^{207} \mathrm{~Pb}$, respectively.

In this study, radiogenic heat productions of marble tiles are calculated based on the elemental concentrations of uranium (in terms of $\mathrm{mg} / \mathrm{kg}$ ), thorium (in terms of $\mathrm{mg} / \mathrm{kg}$ ) and potassium (in terms of $\%)$ in the samples collected from various provinces in Turkey.

\section{Material and Method}

The elemental concentrations (EC) using the following formula:

$$
E C=\frac{W \times A_{C} \times F}{\lambda_{E} \times N_{A v .} \times I A_{E}}
$$

\footnotetext{
*Sorumlu yazar: aybaba@kastamonu.edu.tr

Geliş Tarihi: 15.10.2019, Kabul Tarihi: 19.12.2019
} 
The elemental concentration of ${ }^{238} \mathrm{U}$ was calculated. The radioactive heat production $(\mathrm{H}$ in $\left.\mu \mathrm{W} / \mathrm{m}^{3}\right)$ of given rocks or building materials can be calculated by using the equation [2]:

$H=\rho \times\left(9.52 \times C_{U}+2.56 \times C_{T h}+3.48 \times C_{K}\right) \times 10^{-5}$

where $\rho$ is the bulk density of the rock or building material (in $\mathrm{kg} / \mathrm{m}^{3}$ ), $C_{U}, C_{T h}$ and $C_{K}$ is elemental concentration of $\mathrm{U}$ (in terms of $\mathrm{mg} / \mathrm{kg}$ ), Th (in terms of $\mathrm{mg} / \mathrm{kg}$ ) and $\mathrm{K}$ (in terms of \%), respectively.

\section{Results and Discussion}

The values of elemental concentrations of $\mathrm{U}, \mathrm{Th}$ and $\mathrm{K}$ in marble tile samples, and radiogenic heat productions calculated for marble tile samples are given in Table 1. It is seen from Table 1 that the elemental concentrations of $U$, Th and K varied from 0.1 to $4.6 \mathrm{mg} / \mathrm{kg}$ with an average of $0.7 \mathrm{mg} / \mathrm{kg}$, 0.2 to $20.4 \mathrm{mg} / \mathrm{kg}$ with an average of $1.5 \mathrm{mg} / \mathrm{kg}$ and 0.04 to $2.4 \%$ with an average of $0.2 \%$, respectively. The highest concentration of ${ }^{238} \mathrm{U}$ was measured in marble tile sample coded of MRB5 while the lowest concentration of ${ }^{238} \mathrm{U}$ was measured in marble tile samples coded of MRB17 and MRB25. The highest concentration of ${ }^{232} \mathrm{Th}$ and ${ }^{40} \mathrm{~K}$ was measured in marble tile sample coded of MRB4 while the lowest concentration of ${ }^{232} \mathrm{Th}$ and ${ }^{40} \mathrm{~K}$ was measured in marble tile samples coded of MRB13 and MRB12, respectively. The value of $\mathrm{H}$ from marble samples varied from 0.05 to $2.17 \mu \mathrm{W} / \mathrm{m}^{3}$ with an average of $0.26 \mu \mathrm{W} / \mathrm{m}^{3}$. The highest value of radiogenic heat production was calculated in marble tile sample coded of MRB4. Comparison of the average value of the $\mathrm{H}$ calculated for the marble samples studied with those calculated for different rocks types is given in Table 2. From Table 2, the average value of the marble $\mathrm{H}$ is lower than those of rock types.

\section{Conclusions}

The average of concentration of $\mathrm{U}$, Th and $\mathrm{K}$ in marble samples is lower than the average value of earth's crust of $2.5,13$ and $25000 \mathrm{mg} / \mathrm{kg}$, respectively [6]. The average of the radiogenic heat production of the marble tile samples is approximately four times lower than the average continental crust of $0.9 \mu \mathrm{W} / \mathrm{m}^{3}$. The contribution of ${ }^{238} \mathrm{U},{ }^{232} \mathrm{Th}$ and ${ }^{40} \mathrm{~K}$ to total radiogenic heat production is estimated as $60 \%, 34 \%$ and $6 \%$, respectively. The results revealed that radiogenic heat production by the marble samples varies according to the geological structure of the region.

Table 1. The values of radiogenic heat production of the marble samples

\begin{tabular}{|c|c|c|c|c|}
\hline \multirow[t]{2}{*}{ Sample code } & ${ }^{238} \mathrm{U}$ & ${ }^{232} \mathrm{Th}$ & ${ }^{40} \mathrm{~K}$ & \multirow[t]{2}{*}{$\mathrm{H}\left(\mu \mathrm{W} / \mathrm{m}^{3}\right)$} \\
\hline & $\mathrm{mg} / \mathrm{kg}$ & $\mathrm{mg} / \mathrm{kg}$ & $(\%)$ & \\
\hline MRB1 & 0.3 & 0.8 & 0.2 & 0.13 \\
\hline MRB2 & 0.9 & 1.1 & 0.2 & 0.30 \\
\hline MRB3 & 0.6 & 1.0 & 0.2 & 0.21 \\
\hline MRB4 & 3.3 & 20.2 & 2.4 & 2.17 \\
\hline MRB5 & 4.6 & 0.8 & 0.1 & 1.08 \\
\hline MRB6 & 0.3 & 0.8 & 0.1 & 0.11 \\
\hline MRB7 & 2.4 & 0.6 & 0.1 & 0.58 \\
\hline MRB8 & 0.2 & 0.8 & 0.0 & 0.09 \\
\hline MRB9 & 1.9 & 2.3 & 0.3 & 0.59 \\
\hline MRB10 & 0.2 & 0.3 & 0.0 & 0.06 \\
\hline MRB11 & 0.2 & 0.3 & 0.0 & 0.06 \\
\hline MRB12 & 0.2 & 0.3 & 0.0 & 0.06 \\
\hline MRB13 & 0.5 & 0.2 & 0.1 & 0.13 \\
\hline MRB14 & 0.6 & 0.8 & 0.0 & 0.18 \\
\hline MRB15 & 0.3 & 0.6 & 0.1 & 0.11 \\
\hline MRB16 & 0.1 & 0.3 & 0.1 & 0.05 \\
\hline MRB17 & 0.1 & 0.3 & 0.1 & 0.05 \\
\hline MRB18 & 0.2 & 0.5 & 0.1 & 0.08 \\
\hline MRB19 & 0.4 & 0.6 & 0.0 & 0.14 \\
\hline MRB20 & 0.2 & 0.4 & 0.1 & 0.07 \\
\hline MRB21 & 0.1 & 0.5 & 0.1 & 0.06 \\
\hline MRB22 & 0.2 & 0.6 & 0.1 & 0.09 \\
\hline
\end{tabular}




\begin{tabular}{lllll} 
MRB23 & 0.3 & 0.8 & 0.1 & 0.12 \\
MRB24 & 1.2 & 3.0 & 1.2 & 0.55 \\
MRB25 & 0.1 & 0.3 & 0.1 & 0.05 \\
MRB26 & 0.4 & 2.5 & 0.1 & 0.25 \\
MRB27 & 0.5 & 1.1 & 0.1 & 0.19 \\
MRB28 & 0.2 & 0.8 & 0.0 & 0.10 \\
MRB29 & 0.2 & 0.6 & 0.1 & 0.08 \\
MRB30 & 0.3 & 0.6 & 0.1 & 0.10 \\
\hline Average & 0.7 & 1.5 & 0.2 & 0.26 \\
Standard deviation & 1.0 & 3.6 & 0.5 & 0.42 \\
Standard error & 0.2 & 0.7 & 0.1 & 0.08 \\
Min & 0.1 & 0.2 & 0.04 & 0.05 \\
Max & 4.6 & 20.2 & 2.4 & 2.17 \\
\hline
\end{tabular}

Table 2. Comparison of the marble $\mathrm{H}$ with those calculated for different rocks [7]

\begin{tabular}{lc}
\hline Type of Rock & $\mathrm{H}\left(\mu \mathrm{W} / \mathrm{m}^{3}\right)$ \\
\hline Granite (Egypt) & 9.53 \\
Granite (South Africa) & 3.51 \\
Quartz diorite (Egypt) & 1.76 \\
Quartz diorite (California) & 0.40 \\
Acidic rocks & 2.38 \\
Acidic rocks & 2.84 \\
Lamprophyre (Egypt) & 1.74 \\
Swiss Alps & 1.12 \\
Basalt (Egypt) & 0.11 \\
Basalt (Japan) & 0.80 \\
Basalt (Former USSR) & 0.39 \\
Metamorphic (Marble-Turkey) & 0.26 \\
\hline
\end{tabular}

\section{References}

[1] McKenna T.E., Sharp I.M. 1998. Radiogenic heat production in sedimentary rocks of the Gulf of Mexico Basin, South Texas. AAPG Bulletin, 82 (3): 484-496.

[2] Clauser C. 2011. Radiogenic heat production of rocks. In: Harsh Gupta (Ed.), Encyclopedia of Solid Earth Gophysics, 2nd ed., Springer, Dordrecht, preprint.

[3] UNSCEAR (United Nations Scientific Committee on the Effects of Atomic Radiation). 2000. Sources and effects of ionizing radiation. United Nations Publication, New York, USA.

[4] Turhan Ş., Varinlioğlu A. 2012. Radioactivity measurement of primordial radionuclides in and dose evaluation from marble and glazed tiles used as covering building materials in Turkey. Radiation Protection Dosimetry, 151 (3): 546-555.

[5] Rybach L. 1988. Determination of heat production rate. In: Haenel, R., Rybach, L., Stegena, L. (Eds.), Handbook of Terrestrial Heat-Flow Density Determination. Kluwer Academic Publishers, Dordrecht, pp.125-142.

[6] Yaroshevsky A.A. 2006. Abundance of chemical elements in the earth's crust. Geochemistry International, 44 (1): 54-62.

[7] Abbady A.G.E. El-Arabi A.M., Abbady A. 2004. Heat production rate from radioactive elements in igneous and metamorphic rocks in Eastern Desert, Egypt. VII Radiation Physics \& Protection Conference, pp. 287-294, 27-30 November 2004, Ismailia-Egypt. 